\title{
KEY INDICIES OF BUSINESS EFFICIENCY ANALYSIS AND EVALUATION
}

\author{
Proskurina N.M., Dashko I.M., *Faizullina S.A., Kuzmenko A.U. \\ Zaporizhzhia National University \\ Ukraine, 69063, Zaporizhzhia, Zhukovsky str., 66 \\ *Turan University \\ Kazakhstan, 050013, Almaty, street Satpayeva, 16 \\ profauditzp@ukr.net,irina.znu@i.ua, akuzmenko17021992@qmail.com \\ ORCID ID: 0000-0001-8674-1720 \\ ORCID ID: 0000-0001-5784-4237
}

Key words:

accounting, liabilities, debts, creditors, accounts payable, calculations, management.
The article examines the economic essence of the concepts of liabilities, accounts payable, creditors, debt, calculations, accounting for transactions with suppliers and contractors on separate sub-accounts and the use of analytical tables of accounts payable to suppliers and contractors to improve management and control of operations of the enterprise. Today there is no unity of views on the economic essence of these concepts, general economic and accounting terminology, issues of organization of accounting and control over settlements with suppliers and contractors and their management. In modern conditions, effectively organized accounting of payments to suppliers and contractors have a significant impact on the financial condition of the enterprise. The expediency of using off-balance sheet accounts in the working plan of the enterprise's accounts is considered, namely account 010 "Accounts payable" and its sub-accounts, which will allow to control accounts payable under a specific agreement, the term of payment of which has not yet come and overdue debts with domestic and foreign creditors, to prevent overdue or violation of terms of its payment, thereby improving the liquidity and solvency of the enterprise; introduction of sub-accounts of the second order of account 63 "Settlements with suppliers and contractors", which help to assess quickly the status of trade payables in general and for each supplier and contractor and the contract. To improve the accounting of settlements with suppliers, it is proposed to introduce an analytical document "Register of documents for payment". Important issues of the management system in accounting for payments to suppliers at the enterprise are the rational choice of partners to supply the required volumes of goods and materials and the optimization payments for them, so it is advisable to consider the system of criteria for selecting suppliers (quality, reliability, completeness, etc.) using a supplier selection model based on a database: demand; commercial offers; contracts; execution of contracts, which is implemented using a special software interface "Database debugging", that provides opportunities to: change the structure of databases; select records from them; change the location of databases on disk; perform queries to databases; choose the type of access to databases. Such information can be used to manage the enterprise and to analyze trade payables at the enterprise.

\section{УДОСКОНАЛЕННЯ ОБЛІКУ ТА КОНТРОЛЮ РОЗРАХУНКІВ 3 ПОСТАЧАЛЬНИКАМИ ТА ПІДРЯДНИКАМИ ЗА СУЧАСНИХ УМОВ ГОСПОДАРЮВАННЯ}

\author{
Проскуріна Н.М., Дашко І.М., *Файзулліна С.А., Кузьменко А.Ю. \\ Запорізький національний університет \\ Украӥна, 69063, м. Запоріжжя, вул. Жуковського, 66 \\ *Університет Туран \\ Казахстан, 050013, м. Алматы, вул. Сатпаєва, 16 а
}

\begin{abstract}
Ключові слова:
облік, зобов'язання, заборгованість, кредитори, кредиторська заборгованість, розрахунки, управління.
\end{abstract}

У статті досліджено питання економічної суті понять зобов'язання, кредиторська заборгованість, кредитори, заборгованість, розрахунки, обліку операцій з постачальниками і підрядниками на окремих субрахунках і використання аналітичних таблиць обліку кредиторської заборгованості перед постачальниками і підрядниками для підвищення управління та контролю за здійсненими операціями підприємства. На сьогодні немає єдності поглядів щодо економічної суті даних понять, загальноекономічної та бухгалтерської термінології, питань організації обліку та контролю за розрахунками 
3 постачальниками і підрядниками та управління ними. В сучасних умовах ефективно організований облік розрахунків з постачальниками і підрядниками здійснюють неабиякий вплив на фінансовий стан підприємства. Розглянуто доцільність використовувати в робочому плані рахунків підприємства позабалансові рахунки, а саме рахунок 010 «Кредиторська заборгованість» та його субрахунки. які дозволять контролювати кредиторську заборгованість за конкретним договором, термін сплати якої ще не настав та прострочену заборгованість $з$ вітчизняними та іноземними кредиторами, не допускати прострочення чи порушення термінів її сплати, тим самим покращуючи ліквідність та платоспроможність підприємства; введення субрахунків другого порядку рахунку 63 «Розрахунки 3 постачальниками та підрядниками», які допомагають оперативно оцінювати стан товарної кредиторської заборгованості в цілому та за кожним постачальником і підрядником і договором. Для вдосконалення ведення обліку розрахунків з постачальниками запропоновано ввести аналітичний документ «Реєстр документів до сплати». Важливими питаннями системи управління в обліку розрахунків 3 постачальниками на підприємстві є раціональний вибір партнерів щодо постачання необхідних обсягів ТМЦ та оптимізація розрахунків за них, тому доцільно враховувати систему критерії вибору постачальників (якість, надійність, комплектність та інші) за допомогою моделі вибору постачальників, основою якої є базах даних: потреба; комерційні пропозиції; контракти; виконання контрактів, що реалізується за допомогою спеціального програмного інтерфейсу «Налагодження баз даних», який надає можливості: змінювати структуру баз даних; виділяти записи з них; змінювати місцезнаходження баз даних на диску; виконувати запити до баз даних; обирати тип доступу до баз даних. Така інформація може бути використана для управління підприємством та для аналізу товарної кредиторської заборгованості на підприємстві.

\section{Formulation of the problem}

In the course of economic activity each enterprise carries out settlement operations with counterparties. Enterprises receive stocks, goods, services from suppliers and contractors; the settlements with them are the bulk of all settlement operations. Therefore, during the settlement operations, it is necessary to constantly monitor their implementation and reflection in the accounting in order to avoid violations and abuses, as well as to improve constantly this process. In modern conditions, effectively organized accountings of payments to suppliers and contractors have a significant impact on the financial condition of the enterprise. After all, when settling accounts with counterparties there are receivables or payables, which must be controlled clearly and improve constantly its accounting and control over it, to prevent overdue payments and bringing the debt to a state of hopelessness. The solution of this problem is facilitated by the rationalization of information support. The increase in the volume and variety of information is due to the system of socio-economic relations and, in particular, financial relations at the state level and at the level of economic entities. The financial environment determines the functioning and interaction with the settlement system, which mediates financial and economic activities. Calculations, having a permanent, dynamic nature, require certain managerial influences, which are produced on the basis of processing numerical flows of various economic information, the leading role in the aggregate of which belongs to the accounting information. It is possible to control the state of settlement discipline with suppliers and contractors at the enterprise subject to provision that the management is equipped with objective and reliable information, which can be provided only by the company's accounting system.

\section{Analysis of recent research and publications}

The current professional literature highlights the positions of many scientists on the economic nature of the category of liabilities to suppliers and contractors. The study of the peculiarities of accounting for the calculations of the enterprise with suppliers and contractors are considered in the works of many scientists, such as O.S. Borodkin, F.F. Butynets, S.F. Golov, O.M. Golovashtchenko, V.M. Kostiuchenko, T.N. Malkov, N.M. Maliuha, M.Iu. Medvediev, V.V. Narezhnyi, S.A. Nikolaeva, V.F. Palii, M.S. Pushkar, V.O. Shevchuk and others. The works of these researchers reveal the essence of current liabilities, the organization of accounting, as well as their impact on the financial condition of the enterprise. However, there are still issues that need further research: determining the content of liabilities to suppliers and contractors, transparency of their reflection in the reporting, accounting for settlements using promissory notes, organization of accounting calculations in terms of automation, control over settlements with suppliers and contractors, etc. After all, many theoretical provisions concerning the interpretation of the essence of settlements with suppliers and contractors, debts and liabilities to them, their methods of accounting and control need to be further improved. All this affected the level of development of certain theoretical and practical aspects of the accounting process of settlements with suppliers and contractors at the enterprise.

\section{Formulation of the goals of the article}

The purpose of the research is to study the theoretical and practical aspects of the essence of settlements with suppliers and contractors and to develop proposals for improving the accounting and control of settlement transactions with them. 


\section{Presentation of the main research material}

Settlements with suppliers and contractors are mutual settlements of enterprises for inventory, performed work, provided services. Settlement relationships between suppliers (contractors) and buyers arise in the course of economic activity of enterprises and these relations are usually preceded by the conclusion of contracts (contracts) of purchase and sale of inventory, contracts for various works, services and more.

Liaibilities in economic activity indicate that on a competitive market, each producer and seller of goods takes over an informal commitment to satisfy the desires of buyers at the expense of the expected usefulness of the proposed product. This approach to the problem suggests that on the market for goods and services (expected benefits) a process of selling and acquiring liabilities occures. These commitments are informal: they are not documented, but are actually valid. Being a share of working capital, accounts payable accelerates the turnover of working capital and thus affects the increase in income of the enterprise, which is the settlement of them and other changes in assets and capital. Therefore, transactions are called settlement - commodity, when it comes to payment of: products that have a natural - material form (coal, cement, fabric, etc.); services (repair of equipment, buildings, household services); works (scientific and technical development, construction).

Liabilities are debts (indebtedness) of an enterprise that arise mainly from the purchase of goods and services on credit, or loans that the enterprise receives for its financing. Property relations between business entities that appear as a result of such transactions acquire the character of civil law obligations. Article 151 of the Civil Code of Ukraine emphasizes: "By virtue of the obligation, one party (debtor) is obliged to take a certain action in favor of the other party (creditor), such as: transfer property, perform work, pay money, etc. or refrain from certain action, and the creditor has the right to demand from the debtor to perform his duty" [2].

In turn, in UAS11 "Liabilities", approved by the order of the Ministry of Finance of Ukraine from 31.01.2000 № 20, the liability defines as a debt of the enterprise, which arose as a result of past events and repayment of which in the future, as is expected to reduce the resources of the enterprise, which embodying economic benefits [6].

Therefore, comparing the two approaches to determining the subject of research should be noted the following. Both individuals and legal entities can be the subjects of the obligation. These are: creditor - a person who has the right to claim; debtor - a person who has a liability which corresponds to the right of claim of the creditor. Each of the subjects of the liability has rights and obligations, legally the same position and not subordinate to another. In some liabilities, one entity acts solely as a creditor and the other acts solely as a debtor. However, for the most part, each party to the liability is both a creditor and a debtor, as both parties may have rights and obligations to each other. The object of the liability is what the rights and obligations of the subjects are aimed at. Thus, the creditor has the right to demand from the debtor, and the debtor is obliged to take a certain action in favor of the creditor: to transfer property, perform work, pay money.

There is no special standard that defines the methodological principles of formation of accounts payable in accounting and their reflection in the financial statements, and this is not necessary. After all, as already noted, accounts payable are nothing more than goods (real estate and movable property, intangible assets, other non-current tangible assets, low-value perishable items, etc.) or services with the seller of such goods (services). Therefore, the order of formation and reflection of information about liabilities in the reporting is determined by UAS 11 "Liabilities" [6].

In this case, for the recognition of liabilities and their reflection in the accounting, as required by UAS 11, two conditions must be met: their assessment can be reliably determined; there is a possibility of a decrease in economic benefits because of their repayment.

At the same time, certain features should be taken into account when reflecting liabilities under UAS 11.

Firstly, interest-bearing liabilities that are due within twelve months of the balance sheet date should be treated as non-current liabilities, if the original maturity was more than 12 months and there is an agreement for re-registration of this commitment for the long term. This principle is in full compliance with paragraph 63 of International Financial Reporting Standards (IFRS) 1. Long-term liabilities under the loan agreement (if the agreement provides for repayment of obligations at the request of the creditor (lender) in case of breach of conditions related to the financial condition of the entrepreneur - borrower), the terms of which violated, are considered long-term if: the lender before the approval of the financial statements has agreed not to require repayment of liabilities due to breach; no further breaches of the loan agreement are expected within 12 months from the balance sheet date. This principle is also fully consistent with IFRS 1 [2].

Accounts payable is a amount of debt of the enterprise to creditors on a certain date. Accounts payable for goods, works, and services - the amount owed to suppliers and contractors for tangible assets, performed work and tangible services.

Creditors - legal entities and individuals to whom the company owes certain amounts of funds, their equivalents or other assets as a result of past events.

Settlements are a system of relations between legal entities and individuals that arise at the time of practical performance of legally executed financial obligations during the implementation of commodity and noncommodity transactions.

Debt is the status of settlements on financial liabilities at any time.

At each enterprise, the policy of receivables and payables should be not developed separately, but be consistent with each other. From the point of view of accounting, settlement operations are the object of accounting, first, as a dynamic process (payment before, simultaneously or after obtaining of goods, works, services) and, secondly, as a static state, i.e. debt between subjects of calculations. 
Thus, the concepts of "settlements" and "debt" in the vast majority contain references to "liabilities": settlements arise on liabilities or liabilities arise from settlements, debt is a liability or vice versa. That is, there is a need to determine the place of each of the concepts and the relationship between them.

Imperfect accounting of payments to suppliers and contractors can cause a significant amount of accounts payable, which, in turn, will lead to deterioration in the financial condition of the enterprise. The reason for this may be the imperfection of accounting for payments to suppliers and contractors, and the negligence and fraud of employees.

In order to improve the accounting of payments to suppliers and contractors, we propose to use off-balance sheet accounts in the work plan of the enterprise's accounts, namely account 010 "Accounts payable" and its sub-accounts: 0101 "Accounts payable for goods, works, services with domestic suppliers and contractors, payment term of which has not come yet", 0102" Accounts payable for goods, works, services with foreign suppliers and contractors, the payment term of which has not come yet", 0103" Overdue accounts payable for goods, works, services to domestic suppliers and contractors", 0104" Overdue accounts payable debt for goods, works, services to foreign suppliers and contractors.

These sub-accounts facilitate the work of accountants, you do not need to analyze each contract and choose the accounts payable. Such arrears will be kept in off-balance sheet accounts under each agreement separately. Such accounts will help to monitor accounts payable, control the timing of its payment.

Also, to improve the accounting of settlements with suppliers and contractors, it will be more appropriate to introduce sub-accounts of the second order of account 63 "Settlements with suppliers and contractors", in particular: to sub-account 631 "Settlements with domestic suppliers and contractors":

- analytical sub-account 6311 "Debts to suppliers and contractors, the due date of which has not come yet";

- analytical sub-account 6312 "Deferred debts to suppliers and contractors";

- analytical sub-account 6313 "Overdue debts to suppliers and contractors";

Similarly, it is also advisable to open sub-accounts to account 632 "Settlements with foreign suppliers and contractors".

Thus, the proposed sub-accounts help to assess quickly the status of trade payables in general and for each supplier and contractor and contract, as well as to control the maturity.

Important issues of the management system in accounting for payments to suppliers at the enterprise are the rational choice of partners for the supply of the required amount of goods and materials and the optimization of payments for them and their accounting. Various factors can act as criteria for the optimum choice of suppliers: the price which component is transport expenses; conditions on which stocks are purchased, taking into account: their optimal delivery and transportation costs, mode of transport and optimal delivery route.

Thus, due to the variety of factors that need to be considered when choosing suppliers, the position of individual economists on the use of ratings to assess the choice of suppliers is noteworthy. As practice shows, the enterprise's management uses, as a rule, only a price criterion at decision-making on a choice of partners on supply. But this approach is unacceptable, as the purchase price is in last place in the rank of criteria in many cases [2].

Therefore, it is advisable to take into account the system of criteria for selecting suppliers (quality, reliability, completeness, etc.), using the following model:

$$
\sum_{i=1}^{n} X i \frac{L i}{K i}\left(1-H i^{X i}\right) \rightarrow \min ,
$$

where $n$ is the number of potential suppliers; $Ц i(P i)$, $\mathrm{Ki}(\mathrm{Ci}), \mathrm{Hi}(\mathrm{Ri})$ - are respectively the purchase price of this product, the coefficient of competitiveness in quality and the coefficient of reliability of $i$ supplier; $X i-$ is an unknown amount of goods and materials that will be purchased from $i$ supplier.

Based on the proposed model, the decision support system for the selection of suppliers deserves attention; it is based on databases: demand, commercial offers, contracts, execution of contracts; this database is implemented using a special software interface "Database debugging", which provides opportunities to: change the structure of databases; select records from them; change the location of databases on disk; perform queries to databases; select the type of database access.

When making payments on accounts at enterprises, there are problems in controlling the repayment of debts to suppliers, because the payment can be full or partial. So we propose to introduce an analytical document "Register of documents to be paid" to improve the accounting of payments to suppliers (Table 1 ).

The main advantage of this document is that it reflects the balances at the end of the day for each specific account of the supplier at the end of the day and month and allows controlling accounts payable to each supplier and avoiding its delay and transition to a state of hopelessness.

In the future, the analytical table 2 can be used to improve the management and control over the implementation of accounting for the obligations of the enterprise.

Table 1 - Register of documents payable by the enterprise

\begin{tabular}{|l|l|l|l|l|l|l|l|l|l|l|}
\hline № & Supplier & $\begin{array}{c}\text { Name of } \\
\text { goods and } \\
\text { materials }\end{array}$ & $\begin{array}{c}\text { № and } \\
\text { date of } \\
\text { document } \\
\text { to be paid }\end{array}$ & $\begin{array}{c}\text { Amount } \\
\text { with VAT, } \\
\text { UAH. }\end{array}$ & $\begin{array}{c}\text { Payment } \\
\text { term, } \\
\text { days }\end{array}$ & $\begin{array}{c}\text { Payment } \\
\text { amount } \\
\text { with VAT, } \\
\text { UAH }\end{array}$ & $\begin{array}{c}\text { Account } \\
\text { balance at } \\
\text { beginning of } \\
\text { month UAH }\end{array}$ & $\begin{array}{c}\text { Date of } \\
\text { payment } \\
\text { under } \\
\text { contract }\end{array}$ & $\begin{array}{c}\text { Number } \\
\text { of days till } \\
\text { pay }\end{array}$ & $\begin{array}{c}\text { Actual } \\
\text { payment } \\
\text { date }\end{array}$ \\
\hline & & & & & & & & & \\
\hline
\end{tabular}


Table 2 - Analytical table of control and management of accounts payable of the enterprise to suppliers and contractors

\begin{tabular}{|c|c|c|c|c|c|c|c|c|c|c|c|}
\hline \multirow{4}{*}{ № } & \multirow{4}{*}{ Supplier } & \multicolumn{10}{|c|}{ Accounts payable of the enterprise to suppliers and contractors } \\
\hline & & \multirow{3}{*}{ Total } & \multicolumn{3}{|c|}{ including maturity, UAH } & \multicolumn{6}{|c|}{ from it - overdue, UAH } \\
\hline & & & \multirow[b]{2}{*}{$\begin{array}{l}\text { up to } \\
3 \text { months }\end{array}$} & \multirow[b]{2}{*}{$\begin{array}{l}\text { from } 3 \text { to } \\
6 \text { months }\end{array}$} & \multirow[b]{2}{*}{$\begin{array}{l}\text { from } 6 \text { to } \\
12 \text { months }\end{array}$} & \multicolumn{3}{|c|}{ Термін прострочення, дні } & \multirow[b]{2}{*}{$\begin{array}{c}\text { Amount, } \\
\text { UAH }\end{array}$} & \multirow[b]{2}{*}{ Causes } & \multirow[b]{2}{*}{$\begin{array}{c}\text { Measures } \\
\text { taken }\end{array}$} \\
\hline & & & & & & \begin{tabular}{|c|} 
up to \\
3 months
\end{tabular} & $\begin{array}{c}\text { from } 3 \\
\text { to } 6 \text { months }\end{array}$ & $\begin{array}{l}\text { from } 6 \text { to } \\
12 \text { months }\end{array}$ & & & \\
\hline & & & & & & & & & & & \\
\hline & & & & & & & & & & & \\
\hline
\end{tabular}

Thus, summarizing the above, in order to improve the accounting of the enterprise's settlements with suppliers and contractors, we have proposed to:

- use sub-accounts of off-balance sheet account 10, which will allow to control accounts payable under a specific agreement, the maturity of which has not come yet and overdue debts with domestic and foreign creditors, to prevent overdue or late payment, thereby improving liquidity and solvency of the enterprise;

- keep records using sub-accounts of the second order of account 63 , which will reflect the debt, the payment of which has not come yet, deferred and overdue debt and will control and prevent its overdue, which will affect positively the financial condition of the enterprise;

- use an analytical table that will allow to control accounts payable for each supplier and contractor and the terms of its repayment or delay in order to increase control over the accounting of liabilities;

- keep the Register of documents of the enterprise to be paid to suppliers, which will increase the efficiency of accounting work to account the balances on the accounts of suppliers.

These proposals will help to improve accounting and allow to control accounts payable in general, preventing violations of maturity date.

\section{References}

1. Holov, S.F. and Kostiuchenko, V.M. (2000), Bukhhalterskyi oblik za mizhnarodnymy standartamy [Accounting according to international standards], Accounting, Kyiv, Ukraine.

2. The Verkhovna Rada of Ukraine (2012), "International Accounting Standard 1 (IASB 1), Presentation of IASB Financial Statements; Standard, International document ordered from 01.01.2012", available at: http://www.rada.gov.ua (accessed: 16.01.2021).

3. The Verkhovna Rada of Ukraine (2013), "National Regulation (Standard) of Accounting 1 "General requirements for financial reporting”, ordered by the Ministry of Finance of Ukraine from 07.02.2013 № 73 (as amended)", available at: http: //www.rada.gov.ua (accessed: 03.02.2021).

4. The Verkhovna Rada of Ukraine (2010), "Tax Code of Ukraine ordered from 02.12.2010 № 2755-IV (as amended)", available at: http: //www.rada.gov.ua (accessed: 03.02.2021).

5. The Verkhovna Rada of Ukraine (1999), The law of Ukraine "On accounting and financial reporting in Ukraine ordered from 16.07.1999 № 996-XIV (as amended)”, available at: http://www.rada.gov.ua (accessed: 22.01.2021).

6. The Verkhovna Rada of Ukraine (2000), "Regulation (standard) of Accounting 11 "Liabilities ordered by the Ministry of Finance of Ukraine from 31.01.2000 № 20 (as amended)”, available at: http://www.rada.gov.ua (accessed: 03.02.2021).

7. The Verkhovna Rada of Ukraine (2003), “Civil Code of Ukraine from 16.01.2003 № 435-IV (with changes and additions)", available at: http://www.rada.gov.ua (accessed: 01.02.2021). 